\title{
British International Studies Association
}

\section{Review of \\ International \\ Studies}

\section{VOLUME 40 | ISSUE 2 | APRIL 2014}

\section{Editors}

Kimberly Hutchings

Mathias Albert

George Lawson

Jennifer Sterling-Folker 


\section{Review of International Studies}

\author{
Editors \\ Kimberly Hutchings (Lead Editor), London School of \\ Economics and Political Science \\ Mathias Albert, University of Bielefeld
}

\section{Editorial Board}

Tarak Barkawi, London School of Economics and Political Science

Janice Bially Mattern, National University of Singapore

Nick Bisley, La Trobe University

William Brown, Open University

Barry Buzan, London School of Economics and Political Science

Charli Carpenter, University of Massachusetts-Amherst

Steve Chan, University of Colorado

Robert A. Denemark, University of Delaware

Thomas Diez, University of Tübingen

Toni Erskine, Aberystwyth University

Lene Hansen, University of Copenhagen

Gunther Hellmann, University of Frankfurt

Patrick Thaddeus Jackson, American University

Oliver Kessler, University of Erfurt

\begin{abstract}
George Lawson, London School of Economics and Political Science

Jennifer Sterling-Folker, University of Connecticut
\end{abstract}

Milja Kurki, Aberystwyth University

Catherine Lu, McGill University

Craig N. Murphy, Wellesley College

Lara J. Nettelfield, Royal Holloway, University of London

Iver B. Neumann, London School of Economics and

Political Science

Inderjeet Parmar, City University

Oliver Richmond, University of Manchester

Justin Rosenberg, University of Sussex

Leonard Seabrooke, Copenhagen Business School

Laura Shepherd, University of New South Wales

Laura Sjoberg, University of Florida

Stephan Stetter, University of Munich

Hidemi Suganami, Aberystwyth University

Jeffrey W. Taliaferro, Tufts University

Andrew Walter, University of Melbourne

Michael C. Williams, University of Ottawa

\section{(C) British International Studies Association 2014}

\section{Subscriptions}

Review of International Studies (ISSN 0260-2105) is published five times per annum, including one Special Issue, for the British International Studies Association by Cambridge University Press.

The subscription price (excluding VAT) of Volume 40, 2014, is $£ 409$ which includes print and electronic access (USA, Canada and Mexico US\$714) for institutions, £57 (USA, Canada and Mexico US\$86) for individuals which includes print only, ordering direct from the publishers and certifying that the journal is for their personal use. Single parts cost $£ 88$ (USA, Canada and Mexico US\$150). The electronic-only price available to institutional subscribers is $£ 342$ (USA, Canada and Mexico US\$547). EU subscribers (outside the UK) who are not registered for VAT should add VAT at their country's rate. VAT registered subscribers should provide their VAT registration number. Orders, which must be accompanied by payment, may be sent to any bookseller or subscription agent or to the publisher: Cambridge University Press, The Edinburgh Building, Shaftesbury Road, Cambridge CB2 8RU, UK. Orders from the USA, Canada and Mexico should be sent to Cambridge University Press, Journals Fulfillment Department, 100 Brook Hill Drive, West Nyack, New York 10994-2133, USA. Prices include delivery by air. Japanese prices for institutions are available from Kinokuniya Company Ltd, P.O. Box 55, Chitose, Tokyo 156, Japan.

Periodicals postage paid at New York, NY, and at additional mailing offices. POSTMASTER: Send address changes in USA, Canada and Mexico to Review of International Studies, Cambridge University Press, 100 Brook Hill Drive, West Nyack, New York 10994-2133, USA.

\section{Copying}

This journal is registered with the Copyright Clearance Center, 222 Rosewood Drive, Danvers, MA 01923, USA. Organisations in the USA who are also registered with the CCC may therefore copy material (beyond the limits permitted by sections 107 and 108 of US copyright law) subject to payment to CCC of the per-copy fee of $\$ 15.00$. This consent does not extend to multiple copying for promotional or commercial purposes. Code 0260-2105/2014 \$15.00. Organisations authorised by the Copyright Licensing Agency may also copy material subject to the usual conditions.

ISI Tear Sheet Service, 3501 Market Street, Philadelphia, Pennsylvania 19104, USA, is authorised to supply single copies of separate articles for private use only.

For all other use, permission should be sought from Cambridge or the American Branch of Cambridge University Press.

This journal is included in the Cambridge Journals Online service which can be found at journals.cambridge.org/. For further information on other Press titles access cambridge.org/. 


\title{
Review of International Studies
}

\author{
VOLUME 40 . NUMBER 2 . APRIL 2014
}

Lead Editor: Professor Kimberly Hutchings, London School of Economics and Political Science

Co-editors: Professor Mathias Albert, University of Bielefeld

Dr George Lawson, London School of Economics and Political Science

Professor Jennifer Sterling-Folker, University of Connecticut

\section{CONTENTS}

Technocratic manager, imperial agent, or diplomatic champion?

The IMF in the anarchical society

CHRISTIAN BRÜTSCH

In the aftermath of the financial crisis: risk governance and the emergence of pre-emptive surveillance

JOHN GLENN

Postnational discourse, deliberation, and participation toward global risk governance

ANDREAS KLINKE

A turn toward experimentalism? Rethinking security and governance in the twenty-first century

MARK T. NANCE and M. PATRICK COTTRELL

Policy coherency and regime complexes: the case of genetic resources

JEAN-FRÉDÉRIC MORIN and AMANDINE ORSINI

The Ottoman origins of capitalism: uneven and combined development and Eurocentrism

KEREM NISANCIOGLU

Pouvoir, puissance, and politics: Hans Morgenthau's dualistic concept of power?

FELIX RÖSCH

Mechanisms and microfoundations in International Relations theory

WILLIAM MCGINLEY

The legitimacy of transnational NGOs: lessons from the experience of Transparency International in Germany and France 